EETP Vol. 16, 2021, №. 1(59)

ISSN 1896-2327 / e-ISSN 2353-7787

DOI: $10.35765 /$ eetp.2021.1659.10

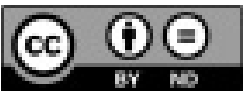

Nadesłano: 3.11 .2020

Zaakceptowano: 8.02.2021

Sugerowane cytowanie: Michalik J. (2021) Motyw odwagi w literaturze dla dzieci a kształtowanie systemu wartości dziecka w młodszym wieku szkolnym, „Edukacja Elementarna w Teorii i Praktyce", vol. 16, nr 1(59), s. 137-149.

DOI: 10.35765/eetp.2021.1659.10

Justyna Michalik

ORICD: 0000-0002-8714-7560

Dolnoślaska Szkoła Wyższa

\title{
Motyw odwagi w literaturze dla dzieci a kształtowanie systemu wartości dziecka w młodszym wieku szkolnym
}

\section{Courage in Children's Literature and Shaping the Value System of a Child at a Younger School Age}

\author{
SŁOWA KLUCZE ABSTRAKT \\ Młodszy wiek Już od wczesnego dzieciństwa, pod wpływem wielu czynników, kształ- \\ szkolny, odwaga, tuje się u dziecka system wartości. Jednym z tych czynników jest lite- \\ literatura dziecięca, ratura dziecięca, tworzona z myślą o dzieciach i dla nich, jako ta, która \\ system wartości, podaje pewne wzorce moralnego postępowania. W niniejszej pracy \\ wychowanie omówiona została kwestia kształtowania systemu wartości dziecka \\ w młodszym wieku szkolnym poprzez dzieła literackie z odwagą w tle. \\ Przedmiotem analizy jakościowej stały się: A. Lindgren, Bracia Lwie \\ serce i C.S. Lewis Opowieści z Narnii, które należą do klasyki literatury \\ dziecięcej. Wybór powyższych książek wynikał głównie z chęci po- \\ znania sposobów wykorzystania powieści w edukacji dziecka w młod- \\ szym wieku szkolnym. Główny wątek artykułu został poprzedzony \\ syntetycznym przeglądem literatury przedmiotu, w którym scharakte- \\ ryzowano pojęcia literatury dziecięcej oraz literatury dla dzieci, warto- \\ ści w życiu dziecka oraz rozwoju i funkcjonowania dziecka w późnym \\ dzieciństwie. Analiza jakościowa wyżej wymienionych dzieł literackich \\ dowiodła, że budowanie świata wartości dzieci w młodszym wieku \\ szkolnym jest możliwe dzięki literaturze tworzonej z myślą o nich.
}




\section{KEYWORDS ABSTRACT}

younger school age, courage, children's

literature, value system, education
Since early childhood, a child's value system is shaped by many factors. One of them includes children's literature created for the youngest readers to provide them with some patterns of moral behaviour. In this article, the author analyses the way of shaping the child's system of values in several works of literature which deal with courage. The following works were subject to qualitative analysis: The Brothers Lionheart by Astrid Lindgren, and The Chronicles of Narnia by C.S. Lewis. Both of them are classic children's books. Choosing them resulted mainly from the willingness to learn how to use a novel in the education of a child at a younger school age. The main issue of this article was preceded by a synthetic analysis of books on the subject, focusing on describing the notions of children's literature and books for children, values in children's life, as well as the development and functioning of a child in late childhood. The qualitative analysis of the above-mentioned literary works proved that building the world of values of younger schoolchildren is possible with the support of books created for them.

\section{Wstęp}

Współcześnie problem wychowania do wartości jest niezwykle złożonym, ale jednocześnie ważnym i aktualnym wyzwaniem stojącym przed edukacją - podkreśla to wielu psychologów, filozofów, pedagogów, oraz nauczycieli praktyków, m.in. Kazimierz Denek, Maria Dzudzikowa, Bogusław Śliwerski, Piotr Oleś, Czesław Kupisiewicz oraz wielu innych. Złożoność tego problemu jest tak duża, że podejmując refleksję na ten temat, w pierwszej kolejności nasuwają się pytania, które uzmysławiają, jak niejasnym zagadnieniem pozostaje istota wychowania człowieka. Wątpliwości związane z wychowaniem do wartości, jak wskazuje Krystyna Chałas (2003), mogą zależeć od wielu czynników, m.in.: przemiany społeczne oraz z sytuacja grupy docelowej dzieci i młodzieży, która implikuje określone wzorce zachowań, powstałe w wyniku tych przemian. Nasuwa się również pytanie o istotę wychowania do wartości w szkole, która poprzez realizację programu wychowawczego „wciela się” w rolę wychowawcy dzieci i młodzieży, stając się tym samym, podobnie jak rodzina, głównym środowiskiem wychowawczym.

Współczesny nauczyciel, stając wobec zmieniających się warunków społeczno-politycznych oraz zmieniających się wymogów prawa oświatowego, musi swoją pracą odpowiedzieć na zaistniałą zmianę; podjąć refleksję nad sobą samym i odpowiedzieć na pytanie: co odrzucić, a co zachować? Odpowiedź ta staje się warunkiem adaptacji nauczyciela do nowej sytuacji, uwzględniającej nowe zjawiska funkcjonowania szkolnictwa i wymogi jego pracy (Nowosad 2001: 263). 
W ujęciu pedagogicznym Kupisiewicz (2009) określa wartości jako coś szczególnie wartościowego dla każdego człowieka. Z kolei Oleś (2002) określa wartości jako przekonanie dotyczące tego co dobre, a co złe, właściwe albo niewłaściwe. $Z$ powyższych definicji wynika, że wartości mogą zostać określone jako cel ludzkich dążeń i pragnień (Krafft 2001:17). Mieczysław Łobocki (1993) do wartości pełniących szczególną rolę zalicza się: altruizm, tolerancję, odpowiedzialność, wolność i sprawiedliwość, jak również dobro, dobroczynność, godność, honor, miłość, piękno oraz wiele innych cech, uznawanych powszechnie przez badaczy - pedagogów, psychologów oraz socjologów, za kształtujące właściwy system wartości. Kształtowanie właściwego systemu wartości jest sumą wielu czynników, do których należą: środowisko rodzinne i szkolne. Oprócz środowiska rodzinnego i szkolnego literatura adresowana do dzieci i młodzieży jest równie cennym nośnikiem wartości. Zdaniem Alicji Ungehauer-Gołąb (2017), zmiany zachodzące we współczesnej rzeczywistości, które obejmują m.in. procesy społeczne, kulturowe czy historyczne, prowadzą do zmiany w postrzeganiu wartości, dlatego też proces wychowania nie może przebiegać bez włączenia do niego dzieł literackich, ponieważ to właśnie literatura daje czytelnikowi szeroki wachlarz możliwości: od pierwotnej wizji świata, po możliwość skonfrontowania jej z otaczającą rzeczywistością, dostarczając młodemu czytelnikowi właściwych wzorców społecznych, ideałów oraz stwarzając tym samym sytuacje do ocen moralnych (Czechowski 2007: 19).

\section{Kilka uwag o dziecku w młodszym wieku szkolnym}

W okresie późnego dzieciństwa zachodzi wiele zmian w rozwoju, poznawczym, społecznym, emocjonalnym, moralnym, w osobowości, w sprawnościach językowych i komunikacyjnych u dzieci. Okres późnego dzieciństwa rozpoczyna się w wieku 6-7 lat, a kończy się wejściem w okres dorastania (10-12 lat). Rozpoczęcie nauki szkolnej w wieku 7 lat jest związane głównie ze zdobywaniem wiedzy, która stanowi podstawową aktywność dziecka również w następnych latach jego życia. Jak podkreśla Anna Kołodziejczyk (2011), zmiany rozwojowe dokonujące się na przestrzeni 6 lat nie odznaczają się szczególną intensywnością w porównaniu z etapem poprzednim czy następnym, niemniej jednak wiedza zdobywana w okresie późnego dzieciństwa jest motorem do zachodzących zmian w tym i następnym okresie życia.

Rozwój poznawczy w okresie późnego dzieciństwa jest związany głównie z eksperymentowaniem, które rozbudza u dzieci ciekawość świata. Zdaniem Kołodziejczyk (2011), kolejną cechą charakterystyczną tego etapu życia na płaszczý́nie rozwoju poznawczego jest zmiana związana z przetwarzaniem informacji, uwagą i pamięcią. Wyżej wymienione zmiany przyczyniają się do poszerzania wiedzy u dziecka, a zmiana otoczenia, która jest związana z rozpoczęciem nauki szkolnej, powoduje tworzenie się 
obrazu u dziecka na temat otaczającej go rzeczywistości. Jak podkreśla Maria Gierowska-Przetacznik (1985), wraz z tymi zmianami zaczyna się tworzyć wiedza społeczna. Zachodzą również zmiany w zakresie sądów, ocen moralnych i postępowania moralnego. Lawrence Kohlberg (1993) uważa, że rozumowanie moralne wiąże się z zachowaniem jednostki, gdyż pozwala na sformułowanie sądów na temat własnych powinności i odpowiedzialności w odniesieniu do konkretnej sytuacji. To, czy dziecko ostatecznie postąpi w określony sposób, zależy także od jego inteligencji czy skupienia i uwagi.

W późnym dzieciństwie oprócz zmian w rozwoju poznawczym, zachodzą również zamiany w rozwoju społecznym i emocjonalnym dziecka. Jedną z cech charakterystycznych tego etapu życia jest zmiana w relacjach społecznych, które wyrażają się w asymilacji z grupą rówieśniczą, w której dziecko odnajduje wsparcie. Henri Wallon (1950) opisując dziecięcy mechanizm naśladownictwa, wskazał, że dziecko identyfikując się z wzorcem, wyodrębnia własne "ja” z otaczającego go świata. Dziecięce naśladowanie jest skierowanie głównie na innych ludzi, zazwyczaj na tych, którzy mu imponują i są dla niego autorytetem (Przetacznikowa 1973:138). W okresie wczesnoszkolnym dziecko postrzega przyjaźn głównie poprzez pryzmat podobnych zainteresowań oraz przez chęć pomocy drugiej osobie. Młodszy wiek szkolny niesie zmiany w rozumieniu emocji. Po pierwsze, rozszerza się krąg zdarzeń i spraw wywołujących przeżycia emocjonalne dziecka, a po drugie, zmienia się i różnicuje charakter doznań emocjonalnych. Jak pisze Elisabeth Hurlock (1960), rozwój społeczny dziecka to zdobywanie dojrzałości do współżycia w społeczeństwie. Jest to proces uczenia się, dostosowywania do nowych wzorców grup społecznych, obyczajów i tradycji oraz poznawania i współdziałania. Prowadzi do nowych sposobów zachowania, nowych zainteresowań i wyboru nowych przyjaciół.

Zmiany w zdolnościach dziecka były przedmiotem poznania wielu badaczy. Jean Piaget (1967) opisując model rozwoju moralnego dziecka, zauważył, że rozumowanie moralne, podobnie jak rozwój poznawczy, jest sterowane przez dwa czynniki: wrodzony i środowiskowy. Zdaniem autora, rozwój ten przebiega dwuetapowo. Oparty dotąd szacunek wobec autorytetu osoby dorosłej - moralność heteronomiczna, przechodzi w późnym dzieciństwie we wzajemny szacunek, równość i sprawiedliwość - autonomia moralna. Z kolei Kohlberg (1993) wyróżnił trzy modele rozwoju moralnego dziecka: przedkonwencjonalny, konwencjonalny i postkonwencjonalny, a każdy z wyżej wymienionych obejmuje dwa stadia rozwoju. Poziom przedkonwencjonalny jest charakterystyczny dla wieku przedszkolnego, jak i wczesnoszkolnego. W pierwszym stadium rozwoju myślenie dziecka jest podporządkowane autorytetowi, głównie z powodu obaw przed konsekwencjami nieposłuszeństwa, natomiast w drugim stadium rozwoju zmienia się ono w myślenie, w którym moralność wiąże się głównie z troską o własne dobro, a rozwój moralny dziecka wyraża się przyjmowaniem przez niego postaw prospołecznych - chęcią pomocy i współpracy. Zdaniem Martina Hoffmana (2006), 
moralne zachowania prospołeczne warunkują dobre funkcjonowanie w społeczeństwie. „Dziecko odczuwa empatię wobec innych osób, pojawia się również autorefleksja. Istotne jest również, że indywidualne doświadczenia wpływają na poziom empatii u dziecka, a jego „rozwój poznawczy jest ściśle związany z rozwojem empatii, w szczególności z rozwojem uczuć moralnych" (Hoffman 2006: 55).

Zdaniem Kołodziejczyk (2011) rozwój osobowości w późnym dzieciństwie obejmuje zmiany związane z zainteresowaniami, uczuciami, temperamentem, zdolnościami, jak również z procesami motywacyjnymi dziecka. W młodszym wieku szkolnym następują u dziecka zmiany w obrazie własnej osoby, które wyrażają się dostrzeganiem różnorodnych cech zewnętrznych, jak również cech dyspozycyjnych. Dziecko w młodszym wieku szkolnym wyraża swoje chęci i pragnienia oraz formułuje pierwsze sądy normatywne, a samoakceptacja odgrywa szczególnie ważną rolę dla rozwoju osobowości dziecka w tym okresie życia. Susan Harter (2003) wyróżniła pięć obszarów, które składają się na samoocenę dziecka: kompetencje szkolne, kompetencje sportowe, kompetencje społeczne, wygląd zewnętrzny, własne postępowania, dowodząc tym, że samoocena u dzieci jest zależna od wielu czynników. Dziecko w młodszym wieku szkolnym do wyżej wymienionych obszarów formułuje samooceny, tworząc obraz psychologiczny własnego „ja” (Harter 2003, za: Kołodziejczyk 2011: 252). Wyżej przytoczone fragmenty wskazują, że u dziecka w okresie późnego dzieciństwa zachodzą istotne zmiany, warunkujące kształtowanie dziecięcego obrazu oraz struktury tego obrazu, dlatego też tak istotną rolę odgrywają opinie oraz zachowanie dorosłych, które determinują kształtowanie właściwego światopoglądu.

\section{Rola literatury w procesie wychowania}

Podejmując rozważania na temat literatury i tego, jaką rolę pełni ona w procesie wychowania, należy zastanowić się, czym właściwie charakteryzuje się literatura dla dzieci. Od wielu lat próby zdefiniowania tego pojęcia budzą na polu debaty naukowej wiele kontrowersji, głównie ze względu na jej zróżnicowany i złożony charakter. Zdaniem Janusza Dunina (1991), literatura adresowana głównie dla najmłodszych odbiorców ukształtowała się stosunkowo późno; dopiero pod koniec XVII wieku fantastyczna bajka ludowa zaczęła wchodzić do literatury, głównie za pośrednictwem Charlesa Perraulta, który napisał Historie i baśnie z dawnych czasów z pouczeniami moralnymi (Kaniowska-Lewańska 1973: 15-16). W literaturze przedmiotu treści przeznaczone dla najmłodszych czytelników zostają zdefiniowane w sposób różnorodny:

Miles McDowell (1991) określa utwory skierowane do dzieci w sposób następujący: 
Książki dla dzieci są z reguły krótsze, wykazują tendencję faworyzowania aktywnego raczej niż pasywnego podejścia, z partiami dialogowymi i z przypadkowymi zdarzeniami zamiast opisów i introspekcji; regułą są dziecięcy bohaterowie; dominują konwencje; akcja rozwija się w oparciu o wyraźny schematyzm moralny ignorowany przez większość literatury dla dorosłych (Oziewicz 2005: 57).

\section{Z kolei Barbara Wall (1991) w The Narrators Voice stwierdza, że:}

Jeśli opowieść została napisana dla dzieci [...] wówczas jest ona dla dzieci, nawet jeśli jednoznacznie może być interesująca dla dorosłych. Jeżeli zaś opowieść nie została napisana dla dzieci, wówczas nie mieści się w gatunku pisarstwa dla dzieci, nawet jeżeli autor lub wydawca ma nadzieję, że spodoba się ona także dzieciom (za: Oziewicz 2005: 58).

Jak pisze Jack Zipes (2006) „literatura dziecięca ma już swoje lata i jest w istocie tak dojrzała, zróżnicowana i złożona, iż niemal niemożliwe jest jej zdefiniowanie, czy choćby opisanie i wyjaśnienie” (za: Skowera 2017: 14).

Z kolei Ryszard Waksmund (1986) uważa, że literatura adresowana dla dzieci jest zjawiskiem normalnym i nieodłącznym, porównywalnym do więzi rodzica z dzieckiem (za: Skowera 2017: 15).

Kimberley Reynolds (2011) jest podobnego zdania co Waksmund (1986): „literatura adresowana do dzieci jest rozumiana jako materiały napisane po to, aby dzieci je czytały” (za: Skowera 2017: 16).

Przywołując pojęcie „literatura dla dzieci”, zostaje ono powszechnie asymilowane z typem literatury, który wykazuje pewne cechy charakterystyczne, pozwalające na rozróżnienie jej od literatury dla dorosłych. Jak pisze Joanna Papuzińska (1978) w praktyce każdy czytelnik odróżnia utwór przeznaczony dla dzieci, nawet jeśli nie będzie miał do dyspozycji żadnych dodatkowych wskazówek w postaci szaty graficznej, ilustracji czy podtytułów.

W literaturze przeznaczonej do najmłodszego czytelnika przeprowadzenie najprostszych granic między epiką a liryką, poezją a prozą, realizmem a fantastyką jest w praktyce bardzo zawiłe, dlatego można by klasyfikować literaturę dziecięcą nie według kryteriów tematyczno-literackich, lecz według kryterium funkcji, jakie pełni ona w procesie wychowania (Czechowski 2007: 12, za: Pauzińska 1978: 35-38).

Dla kogo zostały zatem napisane Opowieści z Narnii? Czy septologia Clive’a S. Lewisa powinna zostać określona jako „literatura dla dzieci” czy „literatura dziecięca”? Jak pisze Jerzy Cieślikowski (1985), „literatura dla dzieci” obejmuje pozycje napisane z myślą o dzieciach, przeznaczone dla dzieci, lub zaadaptowane dla nich z literatury wysokoartystycznej. Natomiast „literatura dziecięca” zdaniem autora Literatury i pop-kultury dziecięcej, to: 
[...] literatura odzwierciedlająca dziecięcy sposób widzenia świata, tworzona jak gdyby w imieniu dziecka „robiona w etologii dziecka” , dzięki czemu w swych najdoskonalszych osiągnięciach stać się ona mogła także przedmiotem zainteresowań i głębokich przeżyć estetycznych człowieka dorosłego (Oziewicz 2015: 62).

Przyjmując podział za Cieślikowskim (1985), w którym wyznacznikiem literatury dziecięcej jest twórczość w „etologii dziecka”, można przyjąć, że Opowieści z Narnii, w których świat przedstawiony nie jest infantylizowany ani „udziecinniony”, ale odwołuje się zarówno do obrazowania pokrewnego wyobraźni dziecka, będąc w dużym stopniu realizacją dziecięcej wyobraźni, jak również adresat, który charakteryzuje się swoiście pojętą wrażliwością przypisaną „dziecięcości”, należą do kanonu literatury dziecięcej (Oziewicz 2005: 104).

Wyżej wymienione definicje zawierają zarówno określenie „literatura dla dzieci”, jak i „literatura dziecięca”. Wydawać by się mogło, że próba zdefiniowania tego pojęcia jest trudnym wyzwaniem, ponieważ zastanawiające jest czy właściwie poprawne jest stosowanie formy „literatura dla dzieci” czy „literatura dziecięca”? Współcześnie można zaobserwować, że na wielu polach obydwa terminy są stosowane równorzędnie. Świadczą o tym określenia międzynarodowe, np.: Kinderliteratur, children's literature, littérature enfantine. W niemieckojęzycznej literaturze przedmiotu czytamy:

Oba pojęcia: dziecko i dzieciństwo zmieniły swoje znaczenie na przestrzeni lat, zmienił się również przedział wiekowy, który kategoryzował wiek dziecięcy. Do lat 60. XX w. stosowano synonim pojęcia młodzież, który oznaczał fazę poprzedzającą życie dorosłe. Pojęcie literatura dziecięca jest pojęciem wieloznacznym: z jednej strony jest literaturą dla dzieci, z drugiej jednak może być literaturą przez nie interpretowaną (Kümmerling-Meibauer 2003: 6-7. [tł. wł.]).

„Literatura jako sfera sztuki ma ogromne możliwości przenoszenia wartości o charakterze duchowym, kulturowym, społecznym, religijnym, a oddziaływanie utworów literackich pozwala najmłodszym na wartościowanie w sferze przeżyć wewnętrznych" (Ungeheuer-Gołąb 2017: 27). Z kolei literatura adresowana do najmłodszych, zdaniem Janusza Homplewicza (2000), jest również źródłem wrażeń, przeżyć i wzruszeń, a obcowanie z nią prowadzi do nieustannej refleksji czytelnika, kształtując jego światopogląd, zrozumienie i poznawanie emocji, rozwijanie uczuć i nabywanie przekonań wypełniając jeden z podstawowych celów wychowawczych. Jak pisze Cieślikowski (1985), literatura dla dzieci posiada stały kanon składający się z pewnych elementów określona tematyka i sposób jej zaprezentowania, a jej złożony charakter dostarcza dzieciom różnorodnych emocji, wzbogacając jej wewnętrznie i pozwalając budować właściwy system wartości. 


\section{Odwaga jako wartość przedstawiona na kartach literatury dziecięcej - analiza jakościowa}

Bracia Lwie Serce Astrid Lindgren oraz Opowieści z Narnii Clive'a Staplesa Lewisa należą do kanonu lektur obowiązujących na drugim etapie edukacyjnym. Zgodnie z przyjętą tematyką niniejszej pracy, wybrane powieści wpisują się w treści podstawy programowej, będąc tym samym odpowiednie dla dziecka w młodszym wieku szkolnym.

Podejmując analizę jakościową wyżej wymienionych dzieł literackich, sformułowano następujące pytania:

w jaki sposób autorzy przedstawiają wartość odwagi?

- w jakich okolicznościach pojawia się odwaga i czy/jak wpływa ona na kształtowanie systemu wartości dziecka?

- jakie korzyści płyną z bycia odważnym?

- jakie są inne obserwowalne cechy bohatera odważnego?

Odwaga w obu powieściach została przedstawiona poprzez bohaterskie czyny głównych bohaterów:

Poniższy fragment powieści Bracia Lwie Serce opisuje zarówno odwagę głównego bohatera, jak i siłę braterskiej miłości, która jest zdolna przezwyciężyć nawet śmierć. W sytuacji zagrożenia życia Karola, Jonatan pokonuje swoje lęki, zdobywa się na odwagę i ratuje brata z pożaru. Autorka, kreując w tak określony sposób sylwetkę głównego bohatera, uzmysławia młodemu czytelnikowi, jaką rolę odgrywają wartości w życiu.

Wczoraj wieczorem niedaleko ulicy Wiciokrzewu wybuchł gwałtowny pożar, powodując całkowite spłonięcie starego, drewnianego domu oraz śmierć jednej osoby. Gdy ogień powstał, w mieszkaniu na drugim piętrze znajdował się sam, chory i leżąc w łóżku dziesięcioletni chłopiec, Karol Lew. Chwilę później wrócił do domu jego trzynastoletni brat Jonatan i zanim ktokolwiek zdołał go powstrzymać, rzucił się do płonącego wnętrza, by ratować brata (Lindgren 1985: 5).

Stałem przy furtce i patrzyłem, jak Jonatan odjeżdża na swoim koniu i ginie we mgle. Tak, tego ranka mgła okrywała Dolinę Wiśni. I wierzcie mi, że gdy tak stałem i patrzyłem, jak mgła go zabiera, jak on się w niej po prostu rozpływa i znika — czułem się tak, jakby mi serce miało od tego pęknąć. Znowu zostałem sam. To było nie do wytrzymania. Jak oszalały ze zmartwienia rzuciłem się do stajni, wyprowadziłem Fialara, wskoczyłem na siodło i ruszyłem za Jonatanem. Muszę go jeszcze raz zobaczyć, zanim go stracę być może na zawsze (Lindgren 1985: 24).

Z kolei C.S. Lewis na kartach Opowieści z Narnii przedstawia młodemu czytelnikowi Piotra, który ratując Zuzannę, dowodzi tym samym swojej odwagi. Główny bohater jako pierwszy przybywa siostrze na pomoc i bez chwili namysłu staje do walki, 
zabijając przeciwnika. Poniższy fragment ukazuje w doskonały sposób, że sukces można osiągnąć jednocząc siły, jak również wskazuje na tragiczne w skutkach konsekwencje źle podjętych decyzji.

Potem zobaczył Zuzannę, jak wyskakuje z namiotu, biegnie do najbliższego drzewa, chwyta się jednej z niższych gałęzi i podciąga do góry. Za nią pędziła jakaś olbrzymia szara bestia. Najpierw wydawało mu się, że to niedźwiedź. Wreszcie zrozumiał, że to wilk. Jedna ze stóp Zuzanny zwisała zaledwie o kilkanaście centymetrów od jego rozwartej paszczy. Piotr zastanawiał się przez moment, dlaczego jego siostra nie wspina się wyżej, zaraz jednak zrozumiał, że była bliska omdlenia. Oznaczało to, że za chwilę spadnie -prosto na tę wściekłą bestię. Piotr nie czuł się wcale mężnie; zrobiło mu się słabo. Nie mogło to jednak mieć żadnego wpływu na to, co musiał zrobić. Natarł na potwora mieczem i wymierzył cios w jego bok (Lewis 1950: 67).

Autorzy przedstawiają na kartach powieści korzyści z bycia odważnym:

A. Lindgren w powieści Bracia Lwie Serce opisuje bohaterski czyn głównego bohatera. Jonatan zostaje doceniony i swoim bohaterskim czynem zyskuje uznanie innych. Za jego odwagę nadano mu przydomek „Lwie Serce” i został porównany do króla Ryszarda „Lwie Serce”.

Drogi Jonatanie Lew, czy nie powinieneś raczej nazywać się Jonatan Lwie Serce? Pamiętasz może, jak czytaliśmy w podręczniku do historii o odważnym królu angielskim Ryszardzie Lwie Serce i ty powiedziałeś wtedy: „I pomyśleć sobie, że ktoś może być tak odważny, że piszą o nim potem w podręczniku do historii. Ja bym takim nigdy nie potrafił być". Kochany Jonatanie, nawet jeżeli nie będą o tobie pisać w podręcznikach do historii, to w tym decydującym momencie byłeś przecież odważny, ty też byłeś bohaterem. Odpoczywaj w pokoju, Jonatanie Lwie Serce! (Lindgren 1985: 6).

W Opowieściach z Narnii Piotr stając do walki z Białą Czarownicą, dowodzi swej odwagi. W zamian zostaje mianowany przez Aslana na króla zamku i od tej pory jest znany jako Piotr Wspaniały.

Walczyli tak zaciekle, że Łucja z trudem mogła się zorientować w przebiegu pojedynku; widziała tylko błyski kling krzemiennego noża Czarownicy i stalowego miecza Piotra, wznoszących się i opadających tak szybko, jakby to były trzy noże i trzy miecze (Lewis 1950: 90).

Wyparli dzikich olbrzymów , kiedy ci przedarli się przez północną granicę Narnii. Zawarli przymierza z krajami poza morzem oraz złożyli tam oficjalne wizyty przyjaźni i przyjęli oficjalne delegacje z tych krajów u siebie. A w miarę jak upływały lata, zmienili się i wydorośleli. Piotr stał się wysokim, barczystym mężczyzną i słynnym rycerzem, a nazywano go królem Piotrem Wspaniałym (Lewis 1950: 93). 
W wyżej wymienionych dziełach literackich, oprócz wartości odwagi, zostają przestawione również inne cechy bohaterów:

Jonatan, główny bohater powieści Bracia Lwie Serce, nazwany jest niezwykle dzielnym i honorowym, ma poczucie własnej godności, pozostając przy tym jednocześnie chłopcem skromnym, uczciwym i szczerym.

Był też miły i silny, wszystko potrafił, wszystko rozumiał, był najlepszy w klasie i wszystkie dzieci z podwórza biegały za nim wszędzie, gdzie szedł, i chciały być z nim, a on obmyślał im różne zabawy i chodził z nimi na różne wyprawy pełne przygód, a ja nigdy nie mogłem brać w tym udziału, bo leżałem całymi dniami na kanapie w kuchni (Lindgren 1985: 4).

Rozumiem — odpowiedział Jossi. — Młody Lwie Serce jest bardziej niebezpieczny od innych, już wam to mówiłem. On naprawdę jest lwem. Poczułem się dumny, że Jonatan jest takim lwem. I jaką pociechą było wiedzieć, że żyje (Lindgren 1985: 35).

$Z$ kolei Piotr z Opowieści z Narnii wyróżnia się takimi cechami jak: troskliwość, opiekuńczość oraz mądrość. Jako najstarszy z rodzeństwa stara się być odpowiedzialny za młodszych, wielokrotnie wykazując się męstwem i walecznością.

„Musisz wysłać zwiadowców, żeby się dowiedzieć, czy ona nie zrobiła tego i tego”, aż w końcu Piotr zauważył: - Ale przecież ty sam z nami będziesz... - Nie mogę ci tego obiecać - odpowiedział Lew i dalej udzielał mu instrukcji. W drugiej części marszu osobami, które towarzyszyły mu najbliżej, były Zuzanna i Łucja. Nie mówił jednak wiele i wydawał się czymś przygnębiony. Było jeszcze jasno, kiedy doszli do miejsca, w którym dolina otworzyła się, a rzeka była szeroka i płytka (Lewis 1950: 75).

Piotr nie mógł się oswoić z myślą, że być może przyjdzie mu poprowadzić walkę i że wielkiego Lwa może zabraknąć w oczekującej ich bitwie. Jedli wieczorny posiłek w milczeniu czując, że wydarzyło się coś, co zupełnie zmieniło sytuację (Lewis 1950: 76).

\section{Próba podsumowania}

Niezależnie od wieku, bohater odważny jest, był i będzie podziwiany, a w każdym z nas budzi się chęć naśladowania go. Odwaga przedstawiona na kartach dzieł literackich jest fascynująca i wzbudza zainteresowanie każdego czytelnika. W procesie wychowania dziecka do wartości ważne jest wsparcie rodziców i opiekunów, ale przekaźnikiem niezmiennie ważnym w budowaniu właściwego systemu wartości jest dzieło literackie. Przywołane w niniejszej pracy fragmenty powieści Opowieści z Narnii oraz Bracia Lwie Serce uczą, że bycie odważnym to nie tylko pokonywanie własnych trudności i lęków, to również przyznanie się do własnych słabości i porażek. Dziecko 
w młodszym wieku szkolnym czytając fragmenty literatury, często utożsamia się z bohaterami powieści, naśladując tym samym postępowanie bohaterów powieści. Odpowiedź na pytanie: czy i jak przekazywana wartość odwagi w literaturze dla dzieci warunkuje wychowanie do wyboru wartości dziecka w młodszym wieku szkolnym, wydaje się być nie tyle oczywista, co jednoznaczna. Literatura skierowana do najmłodszego czytelnika kształtuje jego kręgosłup moralny. Wartości przedstawione w literaturze powodują, że dziecko czytając, pod wpływem treści zawartej na kartach powieści kształtuje indywidualnie określony system wartości. Pomimo że w każdej wyżej wymienionej powieści wartość odwagi została przedstawiona w sposób różnorodny, to uważana jest niezmiennie za jedną z najbardziej cenionych cnót - nikt bowiem nie pragnie uchodzić za tchórza i każdego rozpiera duma, kiedy jest nazywany odważnym. Czasy współczesne, zdominowane przez mass media, stawiają człowieka przed trudnymi wyborami. Obecnie wykorzystywanie środków masowego przekazu jest tak duże, że czasem są one nazywane czwartą władzą. Jednak we współczesnej rzeczywistości można je klasyfikować jako pierwszą władzę, choćby przez pryzmat rosnącej mediokracji (Gębalska-Berekets 2013: 86). Podejmując krytyczną analizę wobec rzeczywistości kreowanej przez media, należy podkreślić, że utwór literacki umożliwia przekraczanie siebie, swoistą transcendencję, która ubogaca odbiorcę, włącza się w proces jego dojrzewania jako człowieka (Głos 2017: 97, za: Sawicki 1994). Powyższe refleksje nad tematem roli, jaką pełni literatura w kształtowaniu systemu wartości dziecka w młodszym wieku szkolnym, zakończę słowami Józefa Tischnera:

Aby zachować się właściwie w tym naszym małym świecie, musimy umieć czytać „wartości”. Nie witamy się z krzesłami, nie usiłujemy szukać dla siebie miejsca na kolanach ludzi już siedzących. Bez koniecznej potrzeby nie siadamy tyłem do katedry. Nasz obecny świat jest niewątpliwie światem jakichś wartości, a my w nim jesteśmy istotami czytającymi wartości (Tischner 1982: 483).

\section{Bibliografia}

Cieślikowski J., Waksmund R. (1985). Literatura osobna, Warszawa: Nasza Księgarnia. Chałas K. (2003). Wychowanie ku wartościom, Lublin-Kielce: Jedność.

Czechowski J. (2007). Funkcje edukacyjnej literatury dla dzieci i mtodzieży, „Kultura i Edukacja” nr 2, s. 10.

Dunin J. (1996). Książeczki dla grzecznych i niegrzecznych dzieci: z dziejów polskich publikacji dla najmtodszych, Wrocław: Ossolineum.

Gębalska-Berekets A. (2013). Znaczenie i rola mediów we wspótczesnej edukacji spoteczeństwa informacyjnego, „Media w Edukacji”, Siedlce: Fundacja na rzecz dzieci i młodzieży.

Gierowska-Przetacznik M. (1985). Psychologia rozwojowa i wychowawcza wieku dziecięcego, Wydawnictwa Szkolne i Pedagogiczne: Warszawa. 
Głos Ł. (2017). Na pograniczu literatury. Z problemów literackości w sztuce XXI wieku, „Annales Universitatis Mariae Curie-Skłodowska” nr 2.

Harter S. (2003). The development of self-reprezentations during childhood and adolescence. [w:] M.R. Leary, J.P. Tangney (red.), Handbook of self and identity. New York, NY: Guildford Press.

Hoffman M.L. (2006). Empatia i rozwój moralny. Gdańsk: Gdańskie Wydawnictwo Psychologiczne.

Homplewicz J. (2000). Etyka Pedagogiczna, Warszawa: WSP.

Hurlock E. (1960). Rozwój dziecka, Warszawa: PWN.

Kaniowska-Lewańska I. (1973) Literatura dla dzieci i mtodzieży do roku 1864. Zarys rozwoju. Wybór materiatów, Warszawa: Wydawnictwa Szkolne i Pedagogiczne.

Kohlberg L. (1993). Rozwój jako cel wychowania, [w:] Z. Kwieciński, L. Witkowski (red.), Spory o edukację. Dylematy i kontrowersje we wspótczesnych pedagogiach. Warszawa: IBE.

Kołodziejczyk A. (2011). Późne dzieciństwo-mtodszy wiek szkolny, [w:] J. Trempała (red.), Psychologia rozwoju cztowieka. Warszawa: Wydawnictwo Naukowe PWN.

Krafft V. (2001). Werte-Erziehung und der Umgang mit ComputernIN: Staatliches.

Seminar für schulpraktischeAusbildung Freudenstadt $(\mathrm{Hg}$.), Werte-Vermittlung und Werte-Erziehung. Berichte aus dem Seminar und Schulaltag, Langenau Ulm: Armin Vaas Verlag.

Kupisiewicz Cz., Kupisiewicz M. (2009). Stownik Pedagogiczny, Warszawa: Wydawnictwo Naukowe PWN.

Kümmerling-Meibauer J. (2003). Kinderliteratur, Kanonbildung und literarische Wertung. Springer-Verlag: Deutschalnd.

Lewis C.S. (1950). Opowieści z Narnii, (tłum.) A. Polkowski). Wrocław: Siedmioróg.

Lindgren A. (1985). Bracia Lwie Serce, (tłum.) T. Chłapowska. Warszawa: Nasza Księgarnia. Łobocki M. (1993). Pedagogika wobec wartości, Kraków: Oficyna Wydawnicza Impuls.

McDowell M. (1991). Fiction for Children and Adults:Some Essential Differences, [za:] P. Hunt (1991). Criticism, Theory and Children's Literature, Oxford: Blackwell Publishing.

Nowosad I. (2001), Nauczyciel-wychowawca czasu polskich przetomów, Kraków: Oficyna Wydawnicza „Impuls”.

Oleś P. (2002). Z badań nad wartościami i wartościowaniem. Niektóre kwestie metodologiczne, „Roczniki Psychologiczne” nr 5, s. 54.

Oziewicz M. (2005). Magiczny urok Narnii: poetyka i filozofia „Opowieści z Narnii” C.S. Lewisa, Kraków: Universitas.

Papuzińska J. (1978). Literatura dla dzieci i mtodzieży-pojęcie i problemy klasyfikacji [w:] Literatura dla dzieci i mtodzieży w procesie wychowania, A. Przecławska (red.) Warszawa: WSiP.

Piaget J. (1967). Rozwój ocen moralnych dziecka, Warszawa: PWN.

Przetacznikowa M. (1973). Podstawy rozwoju psychicznego dzieci i mtodzieży, Warszawa: Państwowe Zakłady Wydawnictw Szkolnych.

Reynolds K. (2011). Children's Literature: A Very Short Introduction. Oxford: Oxford University Press. 
Sawicki S. (1994). Czym jest poezja?. [w:] S. Sawicki. Wartość-sacrum-Norwid. Studia i szkice aksjologiczno-literackie. Lublin: RW KUL.

Skowera M. (2017). Bezpieczna i pożyteczna kraina niedorostości. Literatura dziecięca jako konstrukt, „Gdańskie Czasopismo Humanistyczne” nr 7, s. 14-16.

Tischner J. (1982). Myślenie wedtug wartości, Kraków: Znak.

Ungeheuer-Gołąb A. (2017). Rozważania na temat aksjologii w wychowaniu literackim na przyktadzie toposu królewny, „Edukacja Elementarna w Teorii i Praktyce” vol. 12, nr 3(45), s. 23-37. DOI:10.14632/eetp. 2017.12.45.23.

Waksmund R. (1986). Literatura pokoju dziecinnego, Warszawa: Nasza Księgarnia.

Wall B. (1991). The Narrators Voice. The Dilema of Children's Fiction, London: St. Martin's Press.

Wallon H. (1950). Od myśli do czynu, Warszawa: PZWS.

Zipes J. (2006). The Oxford Encyklopedia of Children's Literature. Vol. 1. Oxford-New York Oxford University Press.

\section{ADRES DO KORESPONDENCJI}

Justyna Michalik

Dolnośląska Szkoła Wyższa

e-mail:michalik.justyna01@gmail.com 